\title{
Manufacture of low-sodium Minas fresh cheese: Effect of the partial replacement of sodium chloride with potassium chloride
}

\author{
A. P. Gomes, ${ }^{*}$ A. G. Cruz, $\dagger^{1}$ R. S. Cadena, $\dagger$ R. M. S. Celeghini, $\dagger$ J. A. F. Faria, $\dagger$ H. M. A. Bolini, $\dagger$ \\ M. A. R. Pollonio, $†$ and D. Granatoł \\ *Universidade de Taubaté (UNITAU), Curso de Engenharia de Alimentos, Estrada Municipal Dr. José Luis Cembranelli, 5000, Fazenda Piloto, \\ Itaim, Taubaté, São Paulo, Brasil CEP12081-010 \\ †Universidade Estadual de Campinas (UNICAMP), Faculdade de Engenharia de Alimentos, Cidade Universitária Zeferino Vaz CEP, 13083-862, \\ Campinas, São Paulo, Brazil \\ fUniversidade de São Paulo (USP), Faculdade de Ciências Farmacêuticas, Av. Prof. Lineu Prestes, 580, B14, 05508-000, São Paulo, \\ São Paulo, Brazil
}

\section{ABSTRACT}

We investigated the effect of sodium reduction by partial substitution of sodium chloride $(\mathrm{NaCl})$ with potassium chloride $(\mathrm{KCl})$ on the manufacture of Minas fresh cheese during $21 \mathrm{~d}$ of refrigerated storage. Four treatments of low-sodium Minas fresh cheese were manufactured, with partial replacement of $\mathrm{NaCl}$ by $\mathrm{KCl}$ at $0,25,50$, and $75 \%$ (wt/wt), respectively. The cheeses showed differences in the content of moisture, ash, protein, salt, and lipid contents, as well as on the extent of proteolysis and hardness throughout the storage period. However, no difference was observed among treatments within each storage day tested. The partial substitution of $\mathrm{NaCl}$ by $\mathrm{KCl}$ decreased up to $51.8 \%$ the sodium concentration of the cheeses produced. The consumer test indicated that it is possible to manufacture a low-sodium Minas fresh cheese that is acceptable to consumers by partial substitution of $\mathrm{NaCl}$ by $\mathrm{KCl}$ at $25 \%$ (wt/wt) in the salting step.

Key words: low-sodium cheese, quality, processing

\section{INTRODUCTION}

Reducing the salt content of foods is currently a major focus of the food industry, particularly in the dairy, meat, and bakery sectors, which are pressured into reformulating their products due to public health agencies, health warnings published in the media, and by consumers looking for a healthy lifestyle (Dewitt, 2008). Excessive consumption of salt is associated with the development of several health complications such as hypertension, kidney stones, and stomach cancer (Durack et al., 2008), besides being harmful to the ab-

Received August 30, 2010.

Accepted February 12, 2011.

${ }^{1}$ Corresponding author: adriano@fea.unicamp.br sorption of calcium in human metabolism, which can negatively affect bone health (Kuwabara, 2010).

Minas fresh (Frescal) cheese is one of the most consumed dairy products in Brazil, being the third most produced cheese in Brazil (after Mozzarella and Prato cheeses); about 50,000 t was produced in 2009 (Lima Filho and Pombo, 2010). It is a fresh white cheese, slightly salted (approximately $20 \%$ wt/wt $\mathrm{NaCl}$ ), and with a slight lactic acid taste produced by the enzymatic coagulation of pasteurized milk with rennet or other appropriate coagulating enzymes. It has a shelf life of about $20 \mathrm{~d}$ under refrigeration (Souza et al., 2008), and its composition and quality are linked directly to the manufacturing processes (Carvalho et al., 2007). Extensive studies covering its probiotic potential (Souza and Saad, 2009) and food safety aspects (Pflanzer Junior et al., 2009; Pinto et al., 2009, 2010) indicate the importance of Minas fresh cheese to the Brazilian people.

Data regarding the sodium intake of the Brazilian population are scarce. Recent research estimates consumption to be approximately $4.7 \mathrm{~g}$ of salt per person in Brazil (Sarmo et al., 2009). Moreover, the percentage of people with hypertension increased from $21.5 \%$ in 2006 to $24.4 \%$ in 2009 , and this number reaches $63 \%$ in the elderly (Sociedade Brasileira de Endocrinologia e Metabologia, 2010). In this context, the development of Minas fresh cheese with a low sodium content is relevant and of interest because this cheese is an ordinary food in Brazil. One reasonable technological option to decrease sodium content in cheeses is to replace sodium chloride with potassium chloride, and in this sense, sensory and chemical analyses should be performed to assess the product's quality compared with conventional cheeses (with sodium chloride). Herein, this research aimed to develop a Minas fresh cheese by partial replacement of $\mathrm{NaCl}$ with $\mathrm{KCl}$, and to evaluate the physico-chemical parameters during refrigerated storage as well as sensory acceptance of the low-sodium cheese. 


\section{MATERIALS AND METHODS}

\section{Cheese Manufacture}

Eighty liters of raw milk (Dairy Cooperative, Vale do Paraíba, São Paulo, Brazil) was pasteurized at $65^{\circ} \mathrm{C}$ for $30 \mathrm{~min}$ and then cooled to $37^{\circ} \mathrm{C}$. Calcium chloride (Doce Aroma, São Paulo, Brazil), prepared from a 40\% (wt/vol) solution, was added at a rate of $0.2 \mathrm{~mL} / \mathrm{L}$ of milk, and the mesophilic lactic culture (Choozit MA 19LYO 50DCU, Danisco Brasil, São Paulo, Brazil) was added at a rate of $1 \%(\mathrm{wt} / \mathrm{vol}$ ) in relation to the total milk used. Powdered rennet (Chr Clerici Power Rennet, Caglificio Clerici, São Paulo, Brazil) was added in accordance with the manufacturer's recommendations. The mixture was homogenized for $2 \mathrm{~min}$ and then left at $37^{\circ} \mathrm{C}$ for $40 \mathrm{~min}$ to coagulate. The curd was cut, the whey run off, and the remaining curd placed in $250 \mathrm{~g}$ plastic molds. The cheeses were submitted to dry salting (NaCl, Sigma, São Paulo, Brazil; $0.8 \%$ wt/wt of the final product), according to the following experiment design: 4 treatments were tested with $\mathrm{KCl}$ (Sigma) replacing part of the $\mathrm{NaCl}$ at $0,25,50$, and $75 \%$ (wt/wt), while keeping the final concentration of salt consistent $(0.8 \% \mathrm{wt} / \mathrm{wt})$ in relation to the total mass of the final product. The cheeses were packaged and sealed in polyethylene plastic bags under vacuum and stored at $5{ }^{\circ} \mathrm{C}$ for $21 \mathrm{~d}$ in a household refrigerator. The experiment was repeated 3 times. The physicochemical and proteolysis analyses and the hardness test were performed at d 1,11 , and 21 of refrigerated storage.

\section{Physicochemical Analysis}

Moisture was determined gravimetrically after drying in an incubator at $105^{\circ} \mathrm{C}$ (Micronal, São Paulo, Brazil) for $24 \mathrm{~h}$. The total content of ash was also determined gravimetrically after heating $2 \mathrm{~g}$ of sample in a muffler furnace (Micronal) at $550^{\circ} \mathrm{C}$. Protein was calculated by determination of total $\mathrm{N}$ by the Kjeldahl method (Brasil, 2006), using a conversion factor of 6.38. The fat content was determined using the Gerber method (Brasil, 2006). The salt content was determined by the Volhard method (Brasil, 2006). The $\mathrm{pH}$ of cheese slurry was determined by blending $20 \mathrm{~g}$ of grated cheese with $12 \mathrm{~mL}$ of distilled water. All analyses used grated cheese samples, followed standard procedures, and were carried out in triplicate (Brasil, 2006).

The minerals were analyzed in triplicate using an inductively coupled plasma optical emission spectroscopy (ICP-OES, model Optima 2000 DV, Perkin Elmer do Brasil, São Paulo, Brazil) with an axial view, power of $1,300 \mathrm{~W}$, gas flow on the plasma of $15 \mathrm{~L} / \mathrm{min}$, and nebulization (spectral) lines of 589.592, 766.490, and 317.933 for sodium, potassium, and calcium (Labsynth,
São Paulo, Brazil), respectively. Details regarding sample preparation are published elsewhere (MorenoRojas et al., 1993)

\section{Proteolysis}

The extent of proteolysis was quantified using a reactive solution (o-phthalaldehyde) containing the following reagents: sodium dodecyl sulfate, sodium tetraborate decahydrate, dithiothreitol, o-phthalaldehyde (Sigma-Aldrich), and ethanol (Labsynth). The extent of proteolysis throughout refrigerated storage was expressed as the absorbance of $o$-phthalaldehyde derivatives at $340 \mathrm{~nm}$ (Masuda et al., 2005).

\section{Hardness}

For the determination of hardness of the cheeses, we used a computerized texture measuring device (Texture Profile Analyzer model TA-XT2, Stable Micro Systems, Godalming, UK). An aluminum probe $25 \mathrm{~mm}$ in diameter was used to compress the cheese samples to $19 \mathrm{~mm}$ in diameter and $20 \mathrm{~mm}$ in height. The measurements were made at $5 \pm 11^{\circ} \mathrm{C}$, a $50 \%$ compression level, and a test speed of $1.0 \mathrm{~mm} / \mathrm{s}$. The test was repeated 5 times for each sample (Fritzen-Freire et al., 2010).

\section{Consumer Test}

The consumer test was performed on the first day of storage. One hundred cheese consumers were recruited at random to take part in the study, the criterion for selection being the nonexistence of allergic reactions to milk. For sensory evaluation, cheese samples were removed from the refrigerator, cut into pieces (dimensions $1.5 \times 1.5 \times 1.5 \mathrm{~cm}$ ), and placed on white plates coded with random 3-digit numbers $1 \mathrm{~h}$ before evaluation at room temperature $\left(20^{\circ} \mathrm{C}\right)$. Consumers were instructed to evaluate the cheeses with respect to degree of liking of appearance, flavor, texture, and overall liking of samples using a 9-point hybrid hedonic scale $(1=$ disliked immensely, 9 = liked immensely; Villanueva and Da Silva, 2009). Between samples, the participants were requested to eat a cream cracker biscuit and drink some water. The first-order and carry-over effects were balanced using a specific design (MacFie et al., 1989) and the samples were presented monadically. All the sensory analyses were carried out in individual booths with controlled temperature and humidity.

\section{Statistical Analysis}

The results of the physicochemical and sensory analysis were initially submitted to the Levene test to verify 
the homogeneity of the variances within treatments. As a second step, a one-way ANOVA was carried out using the samples as the source of variation in the former, and sample and panelist in the latter, respectively. The means for each response variable were compared using the Tukey test (Granato et al., 2011). To evaluate the differences in the molar ratio $(\mathrm{Na}: \mathrm{K})$ and calcium content of the treatments, the $\chi^{2}$ test was applied, using an $\alpha<0.05$. All the analyses were carried out using the software Statistica 7.0 with $95 \%$ of significance (Stat Soft Inc., Tulsa, OK).

\section{RESULTS AND DISCUSSION}

\section{Standard Composition}

Table 1 shows the evolution of physicochemical parameters, proteolysis, and hardness of the cheeses during storage. Differences were observed in all parameters analyzed among the different treatments $(P<0.05)$ throughout the whole storage time; however, no differences were observed among the different treatments on each storage day $(P>0.05)$. All cheeses could be classified as low fat, because the fat content ranged from 10 to $24.9 \%$, and very high moisture, because the moisture values were $>55.0 \%$ (Brasil, 1996). Similar results were found by Silva et al. (2008) when monitoring the physicochemical aspects of low-fat cheeses available in the Brazilian market.

The proteolysis values may be related to the high moisture content, which favors enzymatic reactions such as hydrolytic action of chymosin, which is the major enzyme responsible for the primary proteolysis in fresh cheese (Sousa et al., 2001). Similar results were found for the manufacture of Minas fresh cheese using ultrafiltration retentate and in the manufacture of cheese using ultrafiltration and supplemented with
Lactobacillus acidophilus (Cunha et al., 2002; Ribeiro et al., 2009).

\section{Hardness}

The partial substitution of $\mathrm{NaCl}$ with $\mathrm{KCl}$ resulted in a significant difference in hardness $(P<0.05)$ among the cheeses at the same storage time, with all cheeses produced with $\mathrm{NaCl}-\mathrm{KCl}$ mixtures presenting higher values for this parameter compared with the control cheese $(0 \% \mathrm{KCl})$. This is related to the decreased molar salt levels when $\mathrm{KCl}$ was added in the salting step. Indeed, added salts bind water and hence decrease the water available for solvation of the caseinate, effectively increasing its concentration (Pastorino et al., 2003). However, $\mathrm{KCl}$ has a decreased ionic strength toward $\mathrm{NaCl}$ (Carr et al., 2002), which results in a decreased "salting-out" or solubility of proteins, with a direct effect on the cheese matrix.

Additionally, hardness decreased significantly $(P<$ $0.05)$ in cheeses manufactured with $\mathrm{NaCl}-\mathrm{KCl}$ mixtures compared with the control cheese throughout refrigerated storage. This finding could be related to the increase in proteolysis, probably because of enzymatic hydrolysis of $\alpha$-casein by the coagulant. Indeed, in many types of cheese, the protein matrix is converted into a softer structure during storage (Al-Otaibi and Wilbey, 2006). Similar results were reported during storage of Halloumi cheese that was manufactured with replacement of $\mathrm{NaCl}$ by $\mathrm{KCl}$ (Ayyash et al., 2011).

The effect of reduced $\mathrm{NaCl}$ content on the quality of the cheese may also be dependent on other ingredients, particularly the fat content. The effect of fat in cheese has been widely investigated and the literature is unanimous about the effects of fat on the texture characteristics (Rogers et al., 2009; McMahon, 2010).

Table 1. Evaluation of moisture, fat, protein, proteolysis, salt, $\mathrm{pH}$, and hardness of Minas fresh cheese manufactured with NaCl or mixtures of $\mathrm{NaCl}$ and $\mathrm{KCl}$ during storage ${ }^{1}$

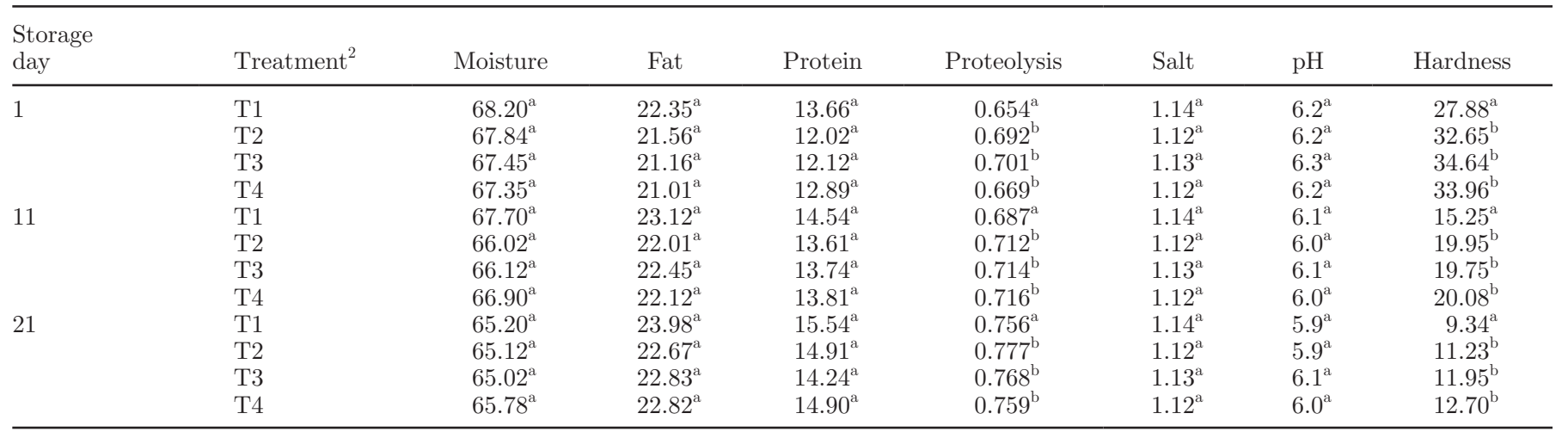

\footnotetext{
${ }^{\mathrm{a}, \mathrm{b}}$ Values within a column and storage day with different superscripts differ significantly $(P<0.05)$.

${ }^{1}$ Moisture, fat, protein, and salt are expressed in percentage by weight; proteolysis is expressed in absorbance at $340 \mathrm{~nm}$.

${ }^{2} \mathrm{~T} 1, \mathrm{~T} 2, \mathrm{~T} 3$, and $\mathrm{T} 4=$ cheeses in which $\mathrm{KCl}$ replaced $0,25,50$, and $75 \%$ of the $\mathrm{NaCl}$ (wt/wt), respectively.
} 


\section{Mineral Content and Nutritional Value}

Table 2 shows the calcium, sodium, and potassium contents in Minas fresh cheese. An increase in the concentration of calcium was observed from 190.7 to $369.69 \mathrm{mg} / 100 \mathrm{~g}$ as the sodium concentration decreased from 103.66 to $57.02 \mathrm{mg} / 100 \mathrm{~g}$ in the product formulation, representing a decrease of up to $51.8 \%$ in the sodium concentration of the cheeses produced. Removal of sodium promotes a decrease in calcium solubilization from the paracasein casein matrix (Guinee, 2004), with a direct effect on the colloidal calcium level, resulting in improved retention of the calcium in the cheese matrix. Obviously, by replacing sodium with potassium, both the gravimetric and the molar ratios of Na:K decreased significantly $(P<0.05)$, as did the calcium content, in accordance with the $\chi^{2}$ test (Table 2 ).

Regardless of the replacement level of salts in the formulation, the cheeses manufactured with substitution of 25,50 , and $75 \% \mathrm{NaCl}$ can be considered lowsodium food products, because they contained less than $120 \mathrm{mg}$ of sodium per $100 \mathrm{~g}$ (Brasil, 1998). Silva and Ferreira (2010) verified that great variation exists in the sodium content of Minas fresh cheeses marketed in Brazil. In full-fat cheeses, the concentration of sodium was between 153 and $383 \mathrm{mg} / 100 \mathrm{~g}$, whereas for low-fat cheeses, sodium was in the range from 171 and 365 $\mathrm{mg} / 100 \mathrm{~g}$. Compared with these results, we observed lower values for Minas fresh cheeses in this study.

\section{Consumer Test}

Table 3 shows the results of the consumer test of the various treatments of low-sodium Minas fresh cheese. The control treatment $(0 \% \mathrm{KCl})$ obtained the highest scores for all sensory attributes evaluated. Salt is strongly related to the overall liking of cheese, and this finding was confirmed by a recent research with Havarti-type cheeses (Ritvanen et al., 2010). The samples with $25 \% \mathrm{KCl}$ had scores similar to that of the control. Indeed, for both of these treatments, all sensory parameters scored 6 (like it slightly) or 7 (like it moderately) on the 9-point hedonic scale. The samples with 50 and $75 \% \mathrm{KCl}$ (wt/wt), respectively, garnered lower scores for taste and texture, related to the increased concentration of potassium chloride, which allowed a greater perception of the bitter taste.

From a sensory point of view, the possibility of producing Minas fresh cheese with $25 \% \mathrm{KCl}$, because this treatment presented results comparable to those of the control treatment T1 (i.e., processed only with sodium chloride) at the consumer test. This demonstrates the ability of sodium chloride to mask the off-flavor caused by the presence of potassium chloride in the formulation when the latter is present in low concentrations. Simultaneously, our findings reinforce the idea that the replacement of sodium by potassium chloride can be successful, especially in cheeses with a decreased level of taste and odor such as Minas fresh cheese (Johnson et al., 2009), which has an average shelf life of $20 \mathrm{~d}$.

Fletcher (2008) stated that $\mathrm{KCl}$ helps to maintain the salty taste and can reduce the amount of salt in food up to $25 \%$ with no losses in palatability; however, the salt attributed a residual sour taste that consumers may consider unsuitable. In fact, the use of salt substitutes such as $\mathrm{KCl}$ is primarily limited by the association of nonsalty flavors, especially bitter flavor. When 2 constituents of flavor are mixed, an interference occurs in taste receptor cells or in taste transduction mechanisms. Sodium salts and constituents of bitterness often interact, removing the bitter taste and enabling the salty taste (Breslin, 1996).

Our results are in agreement with those of other researchers and indicate that production of low-sodium Minas fresh cheese is possible by performing a partial substitution of $\mathrm{NaCl}$ with $\mathrm{KCl}$ at 25 to $50 \%$ (wt/wt; Katsiari and Voutsinas, 1994a,b; Katsiaris et al., 1998; Karagozlu et al., 2008). Additional descriptive tests

Table 2. Contents of calcium, sodium, and potassium of Minas fresh cheeses immediately after manufacture (d 1)

\begin{tabular}{lcccc}
\hline & \multicolumn{4}{c}{ Experimental cheese $^{1}$} \\
\cline { 2 - 4 } Parameter & $\mathrm{T} 1$ & $\mathrm{~T} 2$ & $\mathrm{~T} 3$ & $\mathrm{~T} 4$ \\
\hline Ca (mg per 100 g) & $190.70^{\mathrm{c}}$ & $369.69^{\mathrm{a}}$ & $320.92^{\mathrm{a}}$ & $287.72^{\mathrm{b}}$ \\
Na (mg per 100 g) & 138.31 & 103.66 & 97.46 & 57.02 \\
K (mg per 100 g) & 57.06 & 139.45 & 149.77 & 204.71 \\
Na:K (gravimetric basis) & $2.42^{\mathrm{a}}$ & $0.74^{\mathrm{b}}$ & $0.65^{\mathrm{b}}$ & $0.28^{\mathrm{c}}$ \\
Na:K (molar ratio) & $4.12^{\mathrm{a}}$ & $1.26^{\mathrm{b}}$ & $1.11^{\mathrm{b}}$ & $0.47^{\mathrm{c}}$ \\
\hline
\end{tabular}

${ }^{\mathrm{a}-\mathrm{C}}$ Values within a row with different superscripts in the same line differ significantly $(P<0.05)$ according to $\chi^{2}$ test.

${ }^{1} \mathrm{~T} 1, \mathrm{~T} 2, \mathrm{~T} 3$, and $\mathrm{T} 4=$ cheeses in which $\mathrm{KCl}$ replaced $0,25,50$, and $75 \%$ of the $\mathrm{NaCl}$ (wt/wt), respectively.

${ }^{2}$ Values based on the molecular weight of $\mathrm{Na}=23 \mathrm{~g} / \mathrm{mol}$ and $\mathrm{K}=39.10 \mathrm{~g} / \mathrm{mol}$. 
Table 3. Sensory evaluation based on appearance, flavor, texture, and overall liking of Minas fresh cheeses

\begin{tabular}{lcccc}
\hline & \multicolumn{4}{c}{ Experimental cheese $^{2}$} \\
\cline { 2 - 5 } attribute $^{1}$ & $\mathrm{~T} 1$ & $\mathrm{~T} 2$ & $\mathrm{~T} 3$ & $\mathrm{~T} 4$ \\
\hline Appearance & $7.49^{\mathrm{a}}$ & $7.53^{\mathrm{a}}$ & $7.00^{\mathrm{a}}$ & $7.10^{\mathrm{a}}$ \\
Flavor & $7.02^{\mathrm{a}}$ & $6.40^{\mathrm{b}}$ & $6.25^{\mathrm{b}}$ & $6.15^{\mathrm{c}}$ \\
Texture & $6.89^{\mathrm{a}}$ & $6.91^{\mathrm{a}}$ & $5.91^{\mathrm{b}}$ & $5.83^{\mathrm{b}}$ \\
Overall liking & $7.10^{\mathrm{a}}$ & $6.74^{\mathrm{ab}}$ & $6.10^{\mathrm{b}}$ & $6.02^{\mathrm{b}}$ \\
\hline
\end{tabular}

${ }^{\mathrm{a}-\mathrm{c}}$ Values within a row with different superscripts differ significantly $(P<0.05)$.

${ }^{1}$ Means from 100 respondents and based on a 9-point hedonic scale $(1=$ dislike extremely; $5=$ neither like nor dislike; $9=$ like extremely).

${ }^{2} \mathrm{~T} 1, \mathrm{~T} 2, \mathrm{~T} 3$, and $\mathrm{T} 4=$ cheeses in which $\mathrm{KCl}$ replaced $0,25,50$, and $75 \%$ of the $\mathrm{NaCl}$ (wt/wt), respectively.

should be performed to obtain more complete information about the effect of partial substitution of $\mathrm{NaCl}$ with $\mathrm{KCl}$ in Minas fresh cheese as well as the elaboration of a more instructive label to inform consumers about the health benefits of ingesting a low-sodium cheese. This strategy has been shown to be effective for low-sodium cottage cheese (Drake et al., 2011).

\section{CONCLUSIONS}

The substitution of $\mathrm{NaCl}$ with $\mathrm{KCl}$ in Minas fresh cheese presented significant differences in all parameters analyzed among the different treatments $(P<$ $0.05)$ throughout the storage time. However, no differences were observed among the different treatments within any storage day $(P>0.05)$, except for changes in hardness. The partial substitution of $\mathrm{NaCl}$ with $\mathrm{KCl}$ decreased the sodium concentration of the cheeses up to $51.8 \%$. The consumer test indicated that it is possible to manufacture an acceptable low-sodium Minas fresh cheese by partial substitution $(25 \% \mathrm{wt} / \mathrm{wt})$ of $\mathrm{NaCl}$ with $\mathrm{KCl}$ at the salting step.

\section{REFERENCES}

Al-Otaibi, M. M., and R. A. Wilbey. 2006. Effect of chymosin reduction and salt substitution on the properties of white salted cheese. Int. Dairy J. 15:903-909.

Ayyash, M. M., and N. P. Shah. 2011. Effect of partial substitution of $\mathrm{NaCl}$ with $\mathrm{KCl}$ on proteolysis of Halloumi cheese. J. Food Sci. 75:525-529.

Ayyash, M. M., F. Sherkat, P. Francis, R. P. W. Williams, and N. P. Shah. 2011. The effect of sodium chloride substitution with potassium chloride on texture profile and microstructure of Halloumi cheese. J. Dairy Sci. 94:37-42.

Brasil. 1996. Ministério da Agricultura, Pecuária e Abastecimento. Secretaria de Defesa Agropecuária. Regulamento Técnico de Identidade e Qualidade de Queijos. Accessed July 26, 2010. http:// www.agricultura.gov.br.

Brasil. 1998. Ministério da Saúde. Agência Nacional de Vigilância Sanitária. Portaria número 27. Regulamento técnico referente à informação nutricional complementar. Accessed Nov. 14, 2010. http:// crn6.org.br/legislacao_alimentacao_e_nutricao/portaria.

Brasil. 2006. Ministério da Agricultura, Pecuária e Abastecimento. Secretaria de Defesa Agropecuária. Instrução Normativa no. 68, de 12 de dezembro de 2006. Métodos Analíticos Oficiais Físico-
Químicos, para Controle de Leite e Produtos Lácteos. Accessed July 26, 2010. http://www.agricultura.gov.br.

Breslin, P. A. S. 1996. Interactions among salty, sour and bitter compounds. Trends Food Sci. Technol. 7:390-399.

Carr, J. A., P. A. Munro, and O. H. Campanella. 2002. Effect of added monovalent or divalent cations on the rheology of sodium caseinate solutions. Int. Dairy J. 12:487-492.

Carvalho, J. D. G., W. H. Viotto, and A. Y. Kuaye. 2007. The quality of Minas Frescal cheese produced by different technological processes. Food Contr. 18:262-267.

Cunha, C. R., L. M. Spadoti, P. B. Zacarchenco, and W. H. Viotto. 2002. Efeito do fator de concentração do retentado o rendimento de queijo minas frescal de baixo teor de gordura fabricado por ultrafiltração. Cien. Tecnol. Alim. 22:76-81.

Dewitt, M. C. A. 2008. Processing and ingredients: Sodium reduction. Pages $1-5$ in Reciprocal Meat Conference, Proc. Am. Meat Sci. Assoc., Gainesville, FL. Am. Meat Sci. Assoc., Champaign, IL.

Drake, S. L., K. Lopetcharat, and M. A. Drake. 2011. Salty taste in dairy foods: Can we reduce the salt? J. Dairy Sci. 94:636-645.

Durack, E., M. A. Gonzalez, and M. G. Wilkinson. 2008. Salt: A review of its role in food science and public health. Curr. Nutr. Food Sci. 4:290-297.

Fletcher, A. 2008. Selako salt replacer targets health-conscious consumers. Accessed July 1, 2009. http://www.foodnavigator.com/ Science-Nutrition/Selako-salt-replacer-targets-health-consciousconsumers

Fritzen-Freire, C. B., C. M. O. Muller, J. B. Laurindo, and E. S. Prudêncio. 2010. The influence of Bifidobacterium Bb-12 and lactic acid incorporation on the properties of Minas Frescal cheese. J. Food Eng. 96:621-662.

Granato, D., V. M. A. Calado, and G. F. Branco. 2011. Experimental design and application of response surface methodology for proccess modelling and optimization: A review. Food Res. Int. doi:10.1016/j.foodres.2010.12.008. In press.

Guinee, T. P. 2004. Salting and the role of the salt in cheese. Int. J. Dairy Technol. 57:99-109.

Johnson, M. E., R. Kappor, D. J. McMahon, D. R. McCoy, and R. G. Narasimmon. 2009. Reduction of sodium and fat levels in natural and processed cheeses: Scientific and technological aspects. Comp. Rev. Food Sci. Food Saf. 8:252-266.

Karagozlu, C., O. Kinic, and N. Akbulut. 2008. Effects of the fully and partial substitution of $\mathrm{NaCl}$ by $\mathrm{KCl}$ on physico-chemical and sensory properties. Int. J. Food Sci. Nutr. 59:181-191.

Katsiari, M. C., and L. P. Voutsinas. 1994a. Manufacture of low-fat Feta cheese. Food Chem. 49:53-60.

Katsiari, M. C., and L. P. Voutsinas. 1994b. Manufacture of low-fat Kefalograviera cheese. Int. Dairy J. 4:533-553.

Katsiari, M. C., L. P. Voutsinas, E. Alichanidis, and I. G. Roussis 1998. Manufacture of Kefalograviera cheese with less sodium by partial replacement of $\mathrm{NaCl}$ with $\mathrm{KCl}$. Int. Dairy J. 61:63-70.

Kuwabara, A. 2010. Nutrition and bone health. Dietary sodium intake and bone health. Clin. Calcium 20:590-595.

Lima Filho, R. R., and G. Pombo. 2010. Aumenta o consumo de queijo no Brasil. Carta Leite 6:1-2. 
MacFie, H. J., N. Bratchell, K. Greeenhoff, and L. V. Vallis. 1989. Designs to balance the effect of order of presentation and first-order carry-over effects in hall tests. J. Sens. Stud. 4:129-148.

Masuda, T., R. Yamanari, and T. Itoh. 2005. The trial for production of fresh cheese incorporated probiotic Lactobacillus acidophilus group lactic acid bacteria. Milchwissenschaft 60:167-171.

McMahon, D. J. 2010. Issues with lower fat and lower salt cheeses. Aust. J. Dairy Technol. 65:200-205.

Moreno-Rojas, R., R. Pozo-Lara, G. C. Zurera, and A. M. Lopez. 1993. Calcium, magnesium, manganese, sodium and potassium variations in Manchego-type cheese during ripening. Food Chem. 50:373-378.

Pastorino, A. J., C. L. Hansen, and D. J. McMahon. 2003. Effect of salt on the structure-function relationships of cheese. J. Dairy Sci. 86:60-69.

Pflanzer Junior, S. B., A. G. Cruz, A. S. Sant'ana, M. R. L. Moura, L. M. J. Carvalho, and R. Silva. 2009. Food safety knowledge of cheese consumers. J. Food Sci. 94:28-30.

Pinto, M. S., A. F. Carvalho, A. C. S. Pires, J. C. J. Paula, D. Sobral, and F. A. Magalhães. 2009. Survival of Listeria innocua in Minas Traditional Serro cheese during ripening. Food Contr. 20:11671170 .

Pinto, M. S., A. F. Carvalho, A. C. S. Pires, A. C. C. Souza, P. H F. Souza, D. Sobral, J. C. J. Paula, and A. L. Santos. 2010. The effects of nisin on Staphylococcus aureus count and the physicochemical properties of traditional Minas Serro cheese. Int. Dairy J. 21:90-96.

Ribeiro, E. P., L. G. Simões, and C. H. Jurkiewicz. 2009. Desenvolvimento de queijo minas frescal adicionado de Lactobacillus acidophilus produzido a partir de retentados de ultrafiltração. Cienc. Tecn. Alim. 29:19-23.

Ritvanen, T., L. Lilleberg, T. Tupassis, U. Suhonen, S. Eerola, T. Putkonen, and K. Peltonen. 2010. The characterization of the most- liked reduced-fat Havarti-type cheeses. J. Dairy Sci. 93:50395047.

Rogers, N. R., M. A. Drake, C. R. Daubert, D. J. McMahon, K. Bletsch, and E. A. Foegeding. 2009. The effect of aging on low-fat, reduced-fat, and full-fat Cheddar cheese texture. J. Dairy Sci. 92:4756-4772.

Sarmo, F., R. M. Claro, R. B. Levy, D. H. Bandoni, S. R. G. Ferreira, and C. A. Monteiro. 2009. Estimated sodium intake by the Brazilian population, 2002-2003. Rev. Saude Publica 43:1-6.

Silva, L. F. M., and K. S. Ferreira. 2010. Evaluation of nutritional labelling, centesimal composition and energy value in Minas fresh cheese, fresh Minas "light" and ricotta. Alim. Nutr. 21:437-441.

Silva, R., A. L. D. Batista, A. G. Cruz, M. R. L. Moura, and L. M. J. Carvalho. 2008. Surveillance in low-fat cheese processing. Int. J. Dairy Sci. 3:200-204.

Sociedade Brasileira de Endocrinologia e Metabologia. 2010. Hipertensão sobre no Brasil. Accessed January 17, 2010. http://www. endocrino.org.br/hipertensao-sobe-no-brasil.

Sousa, M. J., Y. Ardö, and P. L. H. McSweeney. 2001. Advances in the study of proteolysis during cheese ripening. Int. Dairy J. 11:327-345.

Souza, C. H. B., and S. M. I. Saad. 2009. Viability of Lactobacillus acidophilus La-5 added solely or in co-culture with a yoghurt starter culture and implications on physico-chemical and related properties of Minas fresh cheese during storage. Lebenson. Wiss. Technol. 42:633-640.

Souza, T. B., A. G. Cruz, M. R. L. Moura, A. P. M. Vieira, and A. S. Sant'Ana. 2008. Microscopic quality indicators of Minas Frescal cheese. Food Contr. 19:71-75.

Villanueva, N., and M. A. A. Da Silva. 2009. Comparative performance of the nine-point hedonic, hybrid and self-adjusting scales in the generation of internal preference maps. Food Qual. Prefer. $20: 1-12$ 